\title{
Las acciones oblicuas o subrogatorias en el federalismo fiscal argentino en defensa de la autonomía municipal
}

\author{
Oblique or Subrogatory Actions in the Argentine \\ Fiscal Federalism in Defence of Municipal Autonomy
}

Tobías Larregui ${ }^{1}$

\section{Resumen}

Las personas se agrupan por lazos íntimos, por necesidad o, simplemente, por espontaneidad. La convivencia es una realidad que nadie puede negar; el hombre no vive solo, y las relaciones interpersonales se hacen insoslayables. He aquí la primera razón sociológica de la existencia del municipio, figura central en la estructura de cualquier Estado, cuya proximidad al ciudadano lo convierte en cauce natural de participación y es responsable directo de un sinnúmero de necesidades básicas.

El presente trabajo busca resaltar la importancia del municipio tantas veces olvidada, tantas veces solapada. Su valor sociológico ha devenido en un reconocimiento constitucional de existencia y autonomía y, pese a haber obtenido tal reconocimiento, ha sido y sigue siendo fuente de debate entre la doctrina política, constitucional y administrativista. De este modo, nos ocuparemos aquí de la situación de los municipios de Argentina frente al federalismo fiscal, a fin de determinar si dichos entes alcanzan la autonomía constitucionalmente garantizada y, en su caso, la legitimación de sus acciones de defensa. Para ello, el núcleo esencial de la presente investigación lo constituye la ley de coparticipación a la luz de la Constitución Nacional, en particular, su funcionamiento irregular, el rol de la Comisión Fe-

\section{Abstract}

People are grouped together either by intimate ties, by necessity or simply by spontaneity. Coexistence is a reality that no one can deny; man does not live alone, and relationships become unavoidable. This is the first sociological reason for the existence of the municipality, central figure in the structure of any State, whose proximity to the citizen makes it a natural channel of participation, and responsible for a number of direct basic needs.

The present work seeks to highlight the importance of the municipality, so often forgotten, so often overlapped. Its sociological value has become a constitutional recognition of existence and autonomy and, despite having obtained such recognition, it has been and continues to be a source of debate among political, constitutional and administrative doctrines.

Thus, this work then focuses on the situation of the municipalities of Argentina with regard to fiscal federalism in order to determine whether these entities achieve constitutionally guaranteed autonomy, and, if so, the legitimacy of their defense actions. To this end, the essential nucleus of the present investigation is the law of co-participation in light of the National Constitution, in particular, its irregular operation, the role of the Federal Tax

\section{Derecho / ensayo científico}

Citar: Larregui, T. (2020). Las acciones oblicuas o subrogatorias en el federalismo fiscal argentino en defensa de la autonomía municipal. Omnia. Derecho y sociedad, 3 (3), pp. 55-82.

1 Universidad Nacional de Córdoba. Abogado, egresado de la Universidad Nacional de Córdoba. Especialista en Derecho Tributario, Universidad Nacional de Córdoba; magíster en Gestión y Administración Pública, Universidad de Cádiz, España; doctorando en Derecho, Universidad de Cádiz, España. Docente adscripto en Derecho Tributario, Universidad Nacional de Córdoba. Docente interino en Legislación Tributaria, Instituto Superior Villa del Rosario, Córdoba. larreguitobias@gmail.com 
deral de Impuestos como autoridad de aplicación y el procedimiento ante ella.

Finalmente, se diagramará un mecanismo de defensa de autonomía municipal en el marco del federalismo fiscal ante situaciones especialmente contempladas, con el objeto de fortalecer institucional y políticamente al ente municipal y así otorgarle la voz y el peso específico que dicho orden de gobierno merece en la materia.

Palabras clave: autonomía municipal - poder tributario - coparticipación - transferencias - acciones oblicuas
Commission as enforcement authority and the procedure before it.

Finally, a defense mechanism of municipal autonomy within the framework of fiscal federalism will be diagrammed in specially contemplated situations, in order to strengthen institutionally and politically the municipal entity, and thus giving it the specific voice and weight that such order of government deserves in the matter.

Keywords: municipal autonomy - tax power co-participation - transfers - oblique actions

\section{INTRODUCCIÓN A LA LEY DE COPARTICIPACIÓN EN SU LABERINTO. SUPUESTOS DE VIOLACIONES A LA LEY}

La historia de las leyes de coparticipación en nuestro país se encuentra cargada de planteos en torno a su constitucionalidad. Nos enseñaba Spisso (2016) que, desde la aparición de este tipo de leyes de armonización de potestades tributarias y distribución de recursos, se despertó un intenso clamor que las juzgaba inconstitucionales por implicar una delegación de poder tributario de las provincias a favor del gobierno nacional. En este punto, hubiera sido conveniente algún planteo ante la Corte Suprema de Justicia, pero lamentablemente no ha ocurrido. No obstante, en el fallo "Madariaga Anchorena Carlos Juan s/Demanda de inconstitucionalidad", de manera trasversal el tribunal señala que

... el ordenamiento vigente en el país admite que las provincias puedan restringir convencionalmente el ejercicio de sus poderes impositivos mediante acuerdos entre sí, y con la Nación, no implicando esto que las provincias se hayan despojado de su potestad impositiva. (Corte Suprema de Justicia de la Nación Argentina [CSJN], 1958, Fallos, 242:280)
Las voces en contra de la constitucionalidad de este tipo de leyes se acallaron, al menos en su faz normativa, con la reforma constitucional de 1994 que viene a diagramar en el art. 75 inc. 2 una suerte de legitimación de las leyes convenio y a situar a la coparticipación en un estadio constitucional, tal como lo señala el máximo tribunal en el fallo "El Cóndor Empresa de Transportes S.A. c/Buenos Aires, Provincia de s/acción declarativa" (CSJN, 2001, Fallos, 324:4226).

Sin embargo, no debemos perder de vista que la actual Ley $\mathrm{N}^{\circ} 23.548$ cuenta con un vicio de origen a causa de su prolongada vigencia, a pesar de ser un "régimen transitorio". La prórroga indefinida al culminar los dos años de su entrada en vigor hasta tanto se sancione una nueva ley de coparticipación la ha trasformado en el más permanente de los regímenes (Bulit Goñi, 2003). Más aún cuando por cláusula transitoria sexta de la Constitución Nacional se ordenaba dictar una nueva ley de coparticipación antes de terminar el año 1996, la cual se encuentra en franco y pasivo incumplimiento.

Actualmente, la Ley $\mathrm{N}^{\circ} 23.548$ es el régimen troncal de la coparticipación federal de impuestos en nuestro país, pero no puede decirse que es el único, ya que existe una serie 
de instrumentos que igualmente forman parte de nuestro federalismo de concertación ${ }^{2}$. En este sentido, existen regímenes especiales de distribución de recursos, como lo encontramos en la Ley № 23.966 de creación de impuesto a los combustibles que supone su coparticipación o la Ley № 24.464 de creación del Sistema Federal de Vivienda, los acuerdos entre los poderes ejecutivos de las provincias y el Estado Nacional conocidos como "pactos fiscales", y la creación de impuestos con afectaciones específicas que disminuyen la masa coparticipable. En definitiva, estos instrumentos producen una serie de detracciones, precoparticipaciones y recortes porcentuales que debilitan el federalismo fiscal en desmedro de los estados provinciales, y producen así lo que se conoce como "laberinto de la coparticipación" ${ }^{\prime \prime}$.

Como primer punto importante, debemos recordar la jerarquía de este tipo de leyes en el marco del federalismo fiscal, es decir, una leyconvenio o bien un instrumento que tiene "cuerpo de contrato y alma de ley", tal como surge de las palabras del constituyente Héctor Masnatta en el diario de sesiones taquigráficas de la Convención Nacional Constituyente (1994).

Más aún, en el fallo "Agueera" (CSJN, 1997, Fallos, 322:1781), si bien referido estrictamente a pactos fiscales, se manifiesta que estos instrumentos forman parte de nuestro federalismo de concertación que parte de los órganos principales de la organización constitucional como lo son las provincias y el Estado Nacional y, por lo tanto, esta particularidad los sitúa en una diversa jerarquía dentro del derecho federal. Por muchos años, la doctrina interpretó que dicha "diversa jerarquía" no era otra cosa que una jerarquía superior, lo que comulgaba con la recepción constitucional de que las leyes-convenio no podían ser modificadas unilateralmente ni reglamentadas.

Dicho pensamiento fue confirmado por la Corte Suprema de Justicia con el fallo "Santa $\mathrm{Fe}^{\prime}$ donde, en palabras del máximo tribunal,

Dichos pactos fiscales, como las demás creaciones legales del federalismo de concertación, configuran el derecho intrafederal y se incorporan una vez ratificados por las legislaturas al derecho público interno de cada Estado provincial, aunque con la diversa jerarquía que les otorga su condición de ser expresión de la voluntad común de los órganos superiores de nuestra organización constitucional: nación y provincias. Esa gestación institucional los ubica con un rango normativo específico dentro del derecho federal. Prueba de su categoría singular es que no es posible su derogación unilateral por cualquiera de las partes (FaIlos: 322:1781 y sus citas).

$8^{\circ}$ ) Que esa jerarquía superior que cabe reconocerle a los acuerdos intrafederales y a las leyes-convenio es inherente a su propia naturaleza contractual en la que concurren las voluntades de los órganos superiores de la Constitución en aras de alcanzar objetivos comunes. (CSJN, 2015, Fallos, 538:2009)

En cuanto a la naturaleza de este tipo de leyes, ha sido denominada "ley-contrato" por la mayor parte de la doctrina, aunque hay quienes ven en ella la naturaleza de tratado

\footnotetext{
${ }^{2}$ Tal como lo entendía el profesor Frías, es decir, bajo la idea de un federalismo no estático o puramente normativo, sino contractual: bajo acuerdo entre la Nación y las provincias, o las provincias entre sí (Frías, 1998).

3 Expresión acuñada en 1995 por el profesor de la Universidad de Toronto Richard Bird en el marco de su visita como invitado a la Argentina, en su función de consultor del Banco Mundial, recordado por Casas (1996).
} 
interprovincial (Pérez Hualde, 1999). Lo que no está en discusión es el origen o germen de este tipo de leyes, que parte de acuerdos previos entre Nación y estados provinciales, tal como surge del art. 75 inc. 2 de nuestra Constitución Nacional, lo que nos sitúa en el concepto de "pacto". Si bien el párrafo n. 5 del artículo citado establece el requisito de la "aprobación" de la ley por parte del estado provincial, debe entenderse como "adhesión", de lo cual se puede concluir que ni está obligada la provincia a someterse a ella, ni su adhesión la somete con carácter retroactivo al momento del dictado de la ley.

Pérez Hualde (1999), en sabias palabras, plantea:

Las provincias adhieren o no a una ley que pretende instrumentar el ejercicio de una facultad compartida, que invisten Nación y Provincia, y que ha sido elaborada sobre la base de acuerdos en los cuales ellas han sido participantes activas. Las provincias se adhieren porque sin su concurso esa norma carece por completo de validez. (p. 69)

Por consiguiente, dada esta estructura y naturaleza particular de las leyes-convenio propias de nuestro federalismo de concertación, surge la imposibilidad de su reglamentación o modificación unilateral, en el sentido establecido por la Constitución Nacional en el artículo 75 inciso 2. La única forma o procedimiento válido para modificar algún aspecto de nuestra coparticipación o demás pactos en la materia es mediante otra ley con el acuerdo pertinente de las provincias ${ }^{4}$, de modo esta se incorpore al derecho interno provincial con jerarquía superior.
Lamentablemente, todo lo expresado anteriormente no se condice con la realidad. La Ley $N^{\circ} 23.548$, como régimen troncal, no opera tal cual como fue diseñada.

\section{LOS PACTOS FISCALES}

El 12 de agosto de 1992, el presidente, para entonces Dr. Carlos Menem, suscribe con los gobernadores provinciales un acuerdo fiscal, cuyo objetivo principal era "asistir a las necesidades sociales básicas, especialmente aquellas vinculadas al sector pasivo", lo cual recibió el nombre de "Pacto Fiscal I", ratificado luego por Ley $\mathrm{N}^{\circ} 24.130$.

Dicho pacto, entre diferentes materias de claro contenido económico y social en lo referente a coparticipación, autoriza al Poder Ejecutivo Nacional a detraer de carácter previo a la distribución primaria hasta un $15 \%$ de la masa coparticipable con destino al financiamiento de sistema de la seguridad social, y hasta un monto fijo de $\$ 43.800 .000$ mensuales para atender desequilibrios fiscales de determinadas provincias. La aceptación de las provincias implicaba el compromiso de Nación de garantizarles en concepto de coparticipación conjunta mensual un monto de $\$ 727.000 .000$.

Por su parte, el 12 de agosto de 1993, el gobierno federal y los estados provinciales acuerdan un nuevo pacto, conocido como "Pacto Fiscal II" (Decreto N 14/94). El principal objetivo de este nuevo pacto era la política tributaria, para lo cual las provincias asumían una serie importante de obligaciones que giraban en torno a suprimir o modificar impuestos provinciales que se consideraban distorsivos. Asimismo, el pacto aumentaba la detracción

\footnotetext{
4 Dicha conclusión es sustentada no solo por las resoluciones interpretativas 12/92 y 13/92 de la Comisión Federal de Impuestos, sino también por dictámenes de la Procuración del Tesoro de la Nación (Dictámenes 103-6 y 201-36).
} 
mensual para cubrir desfinanciamiento de provincias de $\$ 43.000 .000$ a $\$ 45.800 .000$. Las obligaciones asumidas en el marco del acuerdo por parte de las provincias eran algunas de cumplimiento inmediato y otras de cumplimiento progresivo. Como contrapartida, el Estado Nacional se obligaba a aumentar la garantía mínima de coparticipación a las provincias de $\$ 727.000 .000$ a $\$ 740.000 .000$.

En este punto, es conveniente recordar que este pacto fue prorrogado de manera sucesiva por diferentes leyes nacionales, lo cual llevó a determinar su vencimiento en 2006, por lo cual se decidió su incorporación de manera unilateral por parte del Estado nacional en la ley de presupuesto № 26.078. La disposición en la ley de presupuesto que procedía a prorrogar el Pacto Fiscal II no fue ratificada por todas las provincias y dio lugar, en palabras de Bertea (2011), a un "mapa asimétrico" en el cumplimiento de las obligaciones tributarias de las provincias, sumado a la desigual vigencia de ratificaciones que el Pacto Fiscal II contenía del Pacto Fiscal I.

Entre estas últimas ratificaciones contenidas en el Pacto Fiscal II sobre el Pacto Fiscal I, encontramos la detracción previa a la mesa coparticipable del $15 \%$ con destino al sistema de seguridad social, que dio lugar al fallo "Santa Fe" anteriormente citado (CSJN, 2015, Fallos, 538:2009), sumado a los fallos de resolución en cadena de "Córdoba" (CSJN, 2015, Fallos, 786:2013) y "San Luis" (CSJN, 2015, FaIlos, 191:2009).

Pueden encontrarse ejemplos de pactos fiscales posteriores en el acuerdo llamado "Primer compromiso federal" suscripto el 6 de diciembre de 1999 y ratificado por Ley No 25.235, el cual eleva la garantía mínima de coparticipación provincial a \$1.350.000.000, con compromisos económicos de las provincias; el "Compromiso federal para el crecimiento y la disciplina fiscal" suscripto de forma definitiva el 20 de noviembre del 2000 y ratificado por la Ley № 25.400, que también recepta obligaciones económicas de las provincias y un compromiso de Nación de elevar la garantía mínima a $\$ 1.364 .000 .000$; y los recientes "Consenso Fiscal de 2017", ratificado por la Ley No 27.429 y su adenda (2018), y el "Consenso Fiscal de 2019" suscripto el 17 de diciembre de 2019 y ratificado por la Ley No 27.542.

Lamentablemente, el recorte de la masa coparticipable no termina aquí. En los primeros años de la década del 90, el gobierno nacional emprendió un fuerte proceso descentralizador del gasto, y transfirió a las provincias los principales servicios que otrora prestaba la Nación, entre ellos, el sistema educativo mediante la Ley № 24.049 y el sistema de salud.

La paradoja es que la transferencia de tales servicios no vino acompañada de la transferencia de las correspondientes "fuentes tributarias" para solventarlos. Nótese que utilizamos comillas, y esto es relevante, ya que lamentablemente lo que las provincias reclaman - aunque muchas lo hagan sin demasiado vigor- es la transferencia de recursos, una especie de transferencia condicionada de $\mathrm{Na}$ ción, cuando lo que debieran reclamar es la reasunción de sus potestades tributarias a fin de solventar el gasto que los servicios transferidos insumen.

\section{EL PROBLEMA DE LAS ASIGNACIONES ESPECÍFICAS}

Dos son los textos normativos que tienen incidencia en este título. Por un lado, la Constitución Nacional que, en su art. 75 inc, 3, establece la facultad del congreso de "establecer y modificar asignaciones específicas de recursos coparticipables, por tiempo determinado, por ley especial aprobada por la mayoría absoluta

Omnia. Derecho y sociedad, núm. 3, 2020: 55-82 
de la totalidad de los miembros de cada Cámara" y, por el otro, la actual ley de coparticipación № 23.548, cuyo artículo 2 establece que la masa coparticipable se constituirá con el producido de todos los impuestos nacionales existentes y a crearse, bajo excepciones, entre otras, de "los impuestos y contribuciones nacionales con afectación específica a propósitos o destinos determinado".

A simple vista, y como señala Spisso (2016), pareciera que nos encontramos ante una facultad exorbitante establecida por la propia Constitución Nacional, que es capaz de desnaturalizar la esencia convencional de la ley convenio, ya que se autorizaría a la Nación a sustraer fondos de la masa coparticipable a las provincias. En otras palabras, estaría modificando lo adherido por la provincia afectada.

A fin de amalgamar la facultad otorgada al Congreso de la Nación sin atentar contra el espíritu federal de este tipo de leyes-convenio, la Corte Suprema de Justicia de la Nación en el fallo "Provincia de Sta. Fe c/Estado Nacional" (2015, Fallos, 538:2009) establece que las asignaciones específicas son un modo de financiación excepcional y, por lo tanto, de interpretación restrictiva, siendo la regla la integralidad de la masa coparticipable.

Al respecto, Bulit Goñi (1995) señala:

En cuanto a cómo se haya debido disponerse esa afectación para sortear la coparticipación, si de manera unilateral por el nivel nacional o concertada con las provincias, advierto que debe efectuarse una diferenciación: 1) Si se trata de una afectación anterior a la reforma constitucional, y posterior a la ley 23.548 , ha de haber sido establecida con el consentimiento de las provincias (art. 2 inc. d. ley 23548). b) En cambio, si se trata de una afectación a disponerse con posterioridad a la vigencia de la reforma constitucional, considero debe entenderse que el nuevo inc. 3 del art. 75 ha venido a abrogar, para lo futuro, al citado art. 2 inc. d, de la ley 23. 548, por lo que tal afectación puede disponerla unilateralmente el nivel nacional, con dos requisitos: Que sea por tiempo determinado y que lo decida una ley especial aprobada por la mayoría absoluta de la totalidad de miembros de cada Cámara. ${ }^{5}$ (p. 984)

Sostenemos esta última interpretación por ser la asumida por la Corte Suprema de Justicia en el fallo oportunamente mencionado que, a la vez, da sustento a los argumentos del Ministerio Publico Fiscal en su dictamen perteneciente a la causa "Provincia de San Luis c/Estado Nacional" (CSJN, 2016, Expediente CSJ 315/2009).

Desafortunadamente, tuvimos que esperar a que una causa judicial llegase a nuestro máximo tribunal de justicia para poner las cosas en el camino correcto. Sea cual fuere la interpretación que se le dé a este tipo de instituto jurídico, lo cierto es que el inc. 3 del art. 75 deja, al menos, abierta la puerta para que una ley dictada en el Congreso de la Nación con las particularidades mencionadas modifique la masa coparticipable y resienta la integralidad como garantía de federalismo.

Las asignaciones específicas, llamadas más bien "afectaciones", fueron el vehículo utilizado "a diestra y siniestra" por parte de la Nación para desligarse de los convenios suscriptos con las provincias en el marco del federalismo

5 Coincidimos con Bertea (2016) cuando señala como requisito adicional consistente la "especificidad de los fondos" a modo de evitar posibles desvíos hacia caja de rentas generales que desnaturalizan este tipo de afectaciones. 
de concertación en materia impositiva de manera unilateral ${ }^{6}$. Lo ideal sería, como plantea correctamente Espeche (2016), que si Nación quiere incluir en la ley-convenio un impuesto con una asignación específica, primero debe sancionar la ley que le quite dicha condición para luego poder incluirla en el régimen y, del mismo modo, si se pretende una detracción en la masa coparticipable por la creación de una afectación específica, se requiere de un acuerdo de voluntades con las provincias mediante ley-convenio.

Así las cosas, mientras no se pongan límites cualitativos y cuantitativos a esta atribución, continuará en franca contradicción con toda la arquitectura establecida por el art. 75 inc. $2^{7}$, por constituir una detracción unilateral de la masa coparticipable.

\section{LA EVOLUCIÓN HACIA UN SISTEMA DE TRASFERENCIAS DIRECTAS}

En tanto el régimen troncal del federalismo fiscal no funciona tal y como fue diagramado por la Ley $\mathrm{N}^{\circ} 23.548$, en palabras de Bertea (2010), “Desde el año 2003 se viene observando un deslizamiento del federalismo fiscal argentino hacia un régimen mixto, donde conviven el de "participación" con el de "transferencias (o asignaciones) condicionadas", también denominado programas federales de gobierno" (p. 57).

Si bien la prolongada utilización del sistema de coparticipaciones en nuestro país nos ha llevado a una idea de que es el único sistema posible, o bien, viable en nuestro país, la experiencia internacional demuestra lo contrario. A pesar de que la reforma constitucional de 1994 nos lleve a pensar incluso que existe impedimento constitucional para optar por otro sistema, la realidad actual nos muestra la clara modificación o tendencia hacia un sistema con cada vez menos asignaciones y más transferencias, y un centralismo feroz del Estado Nacional.

El debilitamiento del federalismo fiscal es notorio, especialmente, cuando de un simple análisis se puede observar que mediante diversos procedimientos es el Estado Nacional quien centraliza la recaudación de los principales impuestos y detrae fondos a las provincias, muchos de ellos posteriormente distribuidos en forma discrecional, sin criterios objetivos reconocibles o con inclinaciones partidistas.

Resulta imperioso recuperar la senda del federalismo $y$, desde nuestra materia, propiciar el cumplimiento constitucional del dictado de una nueva ley de coparticipación con los presupuestos establecidos por los constituyentes. No obstante, tampoco sería descabellado - más bien, sería altamente razonable- pensar en comenzar un diálogo en pos de adoptar un nuevo sistema de distribución de potestades tributarias que respete la autonomía de los niveles de gobierno inferiores.

Sostenemos que no tiene andamiaje jurídico alguno concluir que el constituyente ha sentenciado la viabilidad de únicamente el sistema de coparticipaciones si analizamos el devenir histórico de su inclusión constitucional. Este último tuvo como fundamento acallar las voces que veían una inconstitucionalidad manifiesta de dichas leyes-convenio ante la "renuncia" no válida de potestades tributarias de las provincias.

\footnotetext{
6 Hernández (2008) se pronunciaba al respecto: "en efecto, a las detracciones efectuadas a la distribución primaria mediante el expediente de las asignaciones específicas, que comenzara en el gobierno del Dr. Menem 21, se ha sumado el impuesto al cheque y especialmente, las retenciones a las exportaciones de soja, maíz y trigo" (p. 18).

7 Para profundizar al respecto, véase Spisso (2007).
} 


\section{SUPUESTOS DE VIOLACIONES NO DENUNCIADAS POR LAS PROVINCIAS Y SU INFLUENCIA SOBRE LOS MUNICIPIOS}

La asignación de recursos entraña poder $y$, como tal, es una de las materias más politizadas en nuestro federalismo. Por desgracia, quienes son los principales actores del régimen no siempre alzan sus voces en reclamo de las irregularidades y las violaciones cometidas por el Estado Nacional.

Es importante tener en cuenta que nuestro federalismo fiscal se estructura bajo el llamado "Derecho Intrafederal de Concertación" (CSJN, 1997, Fallos, 322:1781), que se inspira en la búsqueda de un régimen concurrente en el cual las potestades nacionales y locales se unen en el objetivo de lograr una política uniforme en beneficio común. De este modo, el sistema no permite ningún tipo de modificación unilateral, y requiere así la voluntad de todos los sujetos federales que concurren a configurarlo.

Sin embargo, las violaciones existen de igual modo que existen los mecanismos para defender la naturaleza jurídica de ley-convenio, donde la Comisión Federal de Impuestos (como autoridad de aplicación de la Ley $\mathrm{N}^{\circ} 23.548$ ) tiene un rol superlativo en todo el sistema y establece los procedimientos necesarios de reclamo. Pero ni en la ley de coparticipación ni en el reglamento interno de la Comisión Federal de Impuestos se le otorga a esta autoridad o eje de acción alguna cuando la provincia perjudicada por una irregularidad o violación en el marco del federalismo fiscal decide no actuar en consecuencia, es decir, cuando no asume ningún tipo de acción o reclamo en contra del proceder contrario a derecho del Estado Nacional.
Por supuesto, la provincia perjudicada no se encuentra obligada a iniciar el reclamo pertinente, pero de esta forma estamos olvidando una cuestión esencial que parte del art. 123 de la Constitución Nacional, y es el reconocimiento de la autonomía municipal. Esta omisión de actuar por parte de la provincia deja en el desamparo fiscal a sus municipios, los cuales - dada la fuerte concentración de recursos en el Estado Nacional y el paulatino deterioro que se ha ido generando a sus arcas fiscales desde la sanción de la ley № 23.548 a través del concepto técnico de "analogía" se ven imposibilitados de crear sus propias fuentes de financiamiento, cuestión que es clave para entender el contenido del término "autonomía".

De esta forma, no es descabellado pensar que cuando se habla de los problemas económicos de los municipios, en realidad, estamos hablando de un problema estrictamente financiero, de asignación de recursos agravado, por supuesto, por el contexto de crisis que vive el país. Así, tenemos que los municipios se financian o, más bien, subsisten gracias a transferencias directas que provienen mayoritaria y paradójicamente del régimen de coparticipación.

En conclusión, toda violación o irregularidad en la distribución determinará una merma en la masa coparticipable a las provincias, que en definitiva constituyen los principales recursos con los que hoy subsisten los municipios de nuestro país. Por lo tanto, de no reclamarse o denunciarse las constantes violaciones al régimen, el principal perjudicado pasa a ser el municipio. Esto se agrava cuando observamos que el municipio no cuenta con voz en cuestiones de federalismo fiscal (ya que no son considerados sujetos federales) y, más

\footnotetext{
8 "Que se obliga a no aplicar por sí y a que los organismos administrativos y municipales de su jurisdicción, sean o no autárquicos, no apliquen gravámenes locales análogos a los nacionales distribuidos por esta Ley" (Ley № 23.548, art. 9 inc. b).
} 
aún, cuando en la mayoría de las constituciones provinciales se los obliga a respetar los convenios federales firmados por la provincia sin protagonismo en los acuerdos previos.

La ley de coparticipación ratifica en su artículo 10 la vigencia de la Comisión Federal de Impuestos como organismo de control creado por la legislación antecedente, la Ley № 20.221. Acto seguido, el artículo 11 establece como función de dicha Comisión controlar el estricto cumplimiento por parte de los respectivos fiscos de las obligaciones que contraen al aceptar este régimen de distribución.

Ahora bien, al momento de analizar la ordenanza procesal del citado organismo (Resolución de Plenario № 91/2004) se advierte que esta tiene aplicación únicamente ante supuestos contemplados el artículo 11, inciso d) de la Ley № 23.548 , y en aquellas que se deriven del ejercicio de la atribución conferida también a la Comisión Federal por el inciso e) de la misma norma ${ }^{9}$, los cuales se refieren a oposición de gravámenes nacionales o locales a las disposiciones de la ley de coparticipación ${ }^{10} \mathrm{o}$ a la sanción de resoluciones generales interpretativas. Asimismo, del art. 6 del Reglamento Interno de la Comisión Federal de Impuestos (Resolución No 501) se extrae como competencia del Comité Ejecutivo la actuación de oficio o a pedido de las jurisdicciones legitimadas, a fin de decidir si los gravámenes nacionales o locales se oponen o no $-y$, en caso afirmativo, en qué medida- a las disposiciones del régimen de coparticipación ${ }^{11}$.

Pareciera, por lo tanto, que todo procedimiento establecido ante la Comisión Federal de Impuestos que provenga de su actuación de oficio, o bien, a pedido de las jurisdicciones legitimadas se refiere únicamente a supuestos de creación de impuestos análogos a los nacionales coparticipados, situación que se refleja en las obligaciones asumidas por las provincias - para sí y para sus municipios - en el art. 9 inc. b), y por la Nación en el art. 8.

No obstante, de la ley de coparticipación № 23.548 como régimen troncal de nuestro sistema de federalismo fiscal surgen una serie mayor de obligaciones emergentes que son aceptadas sin reservas por los estados concurrentes. De esta forma, el incumplimiento puede encontrarse en cada una de las obligaciones, o en la obligación madre que surge de la naturaleza de régimen concurrente como "federalismo de concertación", imposible de ser modificado de manera unilateral por parte de alguno de los estados intervinientes.

\footnotetext{
9 "La presente Ordenanza Procesal tiene su ámbito específico de aplicación en las causas encuadradas en el artículo 11, inciso d) de la Ley 23.548, en las que se deriven del ejercicio de la atribución conferida también a la Comisión Federal por el inciso e) de la misma norma, en ambos casos con sus equivalentes en iguales incisos del artículo 12 de la Ley 20.221 t.o. en 1979 y sus modificaciones" (Resolución de Plenario № 91/2004, art. 2).

10 "Decidir de oficio o a pedido del Ministerio de Nación, de las provincias o de las municipalidades, si los gravámenes nacionales o locales se oponen o no y, en su caso, en qué medida a las disposiciones de la presente. En igual sentido, intervendrá a pedido de los contribuyentes o asociaciones reconocidas. Sin perjuicio de las obligaciones de aquellos de cumplir las disposiciones fiscales pertinentes. Art. 11 inc. e): Dictar normas generales interpretativas de la presente ley" (Ley $\mathrm{N}^{\circ} 23.548$, art. 11, inc. d).

11 "Serán funciones del Comité Ejecutivo: Decidir de oficio o a pedido del Ministerio de Economía de la Nación, de las provincias, de la Ciudad Autónoma de Buenos Aires o de las Municipalidades, si los gravámenes nacionales o locales se oponen o no, y en su caso en qué medida, a las disposiciones del Régimen de Coparticipación. En igual sentido intervendrá a pedido de los contribuyentes o asociaciones reconocidas, sin perjuicio de la obligación de aquellos de cumplir las disposiciones fiscales pertinentes" (Reglamento Interno Resolución № 501, art. 6 inc. 4).
} 
Particularmente, esta última derivación lógica de la naturaleza concurrente del régimen es la que más debilitamiento ha generado por el actuar del Estado Nacional. Es más, de la ordenanza procesal no se extrae un procedimiento adecuado para su reclamo cuando los estados provinciales afectados por el actuar del Estado Nacional no proceden a su denuncia, ya sea por cuestiones meramente políticas, acuerdos futuros o, sencillamente, por no iniciar un tedioso reclamo.

En consiguiente, en parte, nuestro régimen de federalismo actual es la causa de pasividad de las provincias y de recurrentes acuerdos políticos, donde se reclama más obras o más distribución, y cada vez hay menos responsabilidad en el gasto.

Omitir la denuncia origina perjuicios en los estados municipales. Como dijimos anteriormente, estos no tienen ni voz ni voto en la creación del régimen, ni condición de "parte" ante la Comisión Federal de Impuestos, es decir, no son "sujeto del régimen federal" — se les reserva una simple condición de coadyuvante-y quedan así sometidos al desamparo fiscal.

No olvidemos que, como expresamos anteriormente, los municipios en Argentina viven y subsisten a través de transferencias directas que provienen de este régimen, en tanto por el art. 9 de la Ley $N^{\circ} 23.548$ tienen prohibido crear cualquier impuesto análogo a los coparticipados los cuales, dada la escasez de fuentes tributarias libres, serán prácticamente todos.

En consiguiente, toda violación o irregularidad en la distribución proveniente del régimen producirá una merma en la masa coparticipable, lo cual, si no es reclamado por la provincia afectada, repercutirá en los recursos dirigidos a los municipios, sin darles a estos posibilidad cierta de denuncia alguna, ya que deben respetar todo convenio firmado por la provincia. e-ISSN 2618-4699

\section{EL PROCEDIMIENTO DE DENUNCIA ANTE LA COMISIÓN FEDERAL DE IMPUESTOS EN EL FEDERALISMO FISCAL}

La Comisión Federal de Impuestos, en atención a lo establecido por la ley de coparticipación federal de impuestos en su art. 110, se instituye como la autoridad de aplicación de la ley. Asimismo, la reforma de 1994 eleva el rango del organismo fiscal federal como autoridad de la ley de coparticipación a dictarse, lo cual puede o no coincidir con la actual Comisión Federal de Impuestos, pero, en la medida que este no cambie en la nueva ley de coparticipación a dictarse, debe identificarse con ella (Ekmekdjian, 1997).

Las funciones que hoy en día tiene previsto este organismo federal emergen de la propia Constitución Nacional, de la ley de coparticipación y, en su derivado, de lo normado por la Resolución de Comité Ejecutivo $\mathrm{N}^{\circ} 501 / 2011$. En consiguiente, y como primer punto, decimos que la Comisión Federal de Impuestos tiene el control y fiscalización de todo lo establecido por el art. 75 inc. 2 de la Constitución Nacional. A su vez, en su artículo 11, la ley de coparticipación $N^{\circ} 23.548$ define como funciones de la Comisión, entre otras, el contralor del estricto cumplimiento por parte de los respectivos fiscos de las obligaciones que contraen al aceptar este régimen de distribución, pero, como se verá a continuación, el procedimiento ante esta solo contempla situaciones de analogía tributaria, lo cual muestra inconsistencias respecto de la pasividad provincial.

El procedimiento ante la Comisión Federal de Impuestos es regulado por la Ordenanza Procesal (Comisión Federal de Impuestos, Resolución Plenario No 91/2004), la cual en su artículo primero establece que, conforme a las leyes № 20.221 y 23.548 , toda causa que 
le compete sustanciar a la Comisión Federal de Impuestos se ajustará a sus disposiciones. Sin embargo, acto seguido, en su art. 2, señala que la Ordenanza Procesal tiene ámbito específico de aplicación en las causas encuadradas en el artículo 11, inciso d) de la Ley № 23.548, $y$ en las que se deriven del ejercicio de la atribución conferida también a la Comisión Federal por el inciso e) de la misma norma.

En cuanto a la legitimación para reclamar ante la Comisión Federal de Impuestos, se establece que podrán asumir la condición de parte en el proceso los fiscos contratantes, los contribuyentes y las asociaciones reconocidas, en cuanto resulten afectados. Se deja bien en claro que al hablar de "fiscos contratantes" solo se hace referencia a la Nación, las provincias y, naturalmente, a la Ciudad Autónoma de Buenos Aires, como sujetos propiamente dichos del federalismo fiscal. Por su parte, al hacer mención a los municipios y a los organismos nacionales o provinciales, autárquicos o no, solo se les reserva la calidad de coadyuvantes sin posibilidad de adquirir condición de parte.

Recibida una demanda por el Comité Ejecutivo, bajo los requisitos que el art. 11 de la Ordenanza Procesal prevé, se dará traslado de ella a la Nación o la provincia que corresponda, con entrega de las copias pertinentes para que la conteste en el término de treinta (30) días. Producida la contestación, la Comisión, si así lo considera oportuno, podrá abrir la causa a prueba. Si así ocurriere, producida esta última, se certificará por secretaría y se notificará a las partes para que en plazo de quince días acompañen sus alegatos.

Vencido el plazo para alegar, o bien, declarada de puro derecho la cuestión, se tendrá por concluida la sustanciación de la causa y se dará vista a la asesoría jurídica y -en caso de corresponder- a la asesoría financiera, ante lo cual la Comisión Federal deberá dictar resolución en el término de sesenta (60) días contados desde que fuera corrida la vista aludida, fecha que podrá prorrogarse por razones fundadas según lo establece el art. 15 de la Ordenanza Procesal.

La Ordenanza Procesal prevé, de igual forma, la sustanciación del procedimiento recursivo a las resoluciones del Comité Ejecutivo. En este sentido, las partes podrán solicitar revisión por parte de la Comisión Federal, en escrito que será debidamente fundado y se interpondrá dentro de los sesenta (60) días de la notificación de aquellas, bajo apercibimiento de ser declarado desierto. Del escrito de recurso, se dará traslado a la contraparte que podrá contestarlo en un plazo de diez (10) días.

El plenario de representantes de la Comisión Federal de Impuestos funciona como órgano de segunda instancia. Este, una vez contestado el traslado del recurso o vencido el término para hacerlo, dictará resolución definitiva en el término de sesenta (60) días, salvo que dos tercios de los representantes presentes durante su tratamiento resolvieran prorrogarlo. Si el recurso careciera de fundamento suficiente, se lo declarará desierto.

La resolución de la Comisión Federal de Impuestos adoptada por simple mayoría es definitiva y de cumplimiento obligatorio para los fiscos intervinientes, sin perjuicio del recurso extraordinario ante la Corte Suprema de Justicia de la Nación con arreglo al artículo 14 de la Ley $N^{\circ} 48$, el que no tendrá efecto suspensivo. No obstante, desde el fallo"Transportes Automotores Chevallier" la Corte Suprema de Justicia (1994, Fallos, 310:2092) ha venido desestimando este tipo de recursos.

La Ley de coparticipación № 23.548 establece en su art. 13 que la jurisdicción afectada por una decisión de la Comisión Federal 
de Impuestos deberá informar a la Comisión, dentro de los noventa (90) días corridos contados a partir de la fecha de notificación de la decisión no recurrida, o de los sesenta (60) días corridos contados a partir de la fecha de notificación de la decisión recaída en el período de revisión todas las medidas que haya adoptado para su cumplimiento. Si así no lo hiciera, el organismo federal tiene potestad para ordenar al Banco de la Nación Argentina que se abstenga de transferir a aquella los importes que le correspondan sobre lo producido del impuesto a distribuir análogo al tributo impugnado, hasta tanto se dé cumplimiento a la decisión del organismo.

Asimismo, declarado un tributo análogo a otro coparticipable, queda expedita la vía de reclamo de devolución de lo pagado, sea en vía administrativa o judicial a sus respectivos fiscos por los contribuyentes afectados, sin necesidad de recurrir ante la Comisión Federal de Impuestos.

Por otro lado, independientemente de los casos de existencia de tributos análogos a los coparticipables bajo el procedimiento nombrado anteriormente, la Comisión Federal de Impuestos como autoridad de aplicación del régimen de coparticipación es competente para entender en materia de distribución de los recursos que provienen del Fondo de Aportes del Tesoro Nacional creado por el art. 3 de la Ley № 23.548.

Del mismo modo, la Comisión Federal de Impuestos extiende su control y fiscalización a todo el régimen inherente a nuestro federalismo fiscal, y no solo al troncal ubicado en la Ley $\mathrm{N}^{\circ} 23.548$, por lo cual se reserva competencia sobre los pactos fiscales (Comisión Federal de Impuestos, Resolución General Interpretativa № 10/1992), asignaciones específicas del art. 75 inc. 3 de la Constitución
Nacional (Comisión Federal de Impuestos, Resolución General Interpretativa № 5/1991, Resolución General Interpretativa № 13/1992 y Resolución de Plenario № 97/2004, entre otras) y regímenes especiales de distribución (Comisión Federal de Impuestos, Resolución General Interpretativa No 5/1991 y Resolución General Interpretativa № 9/1992, entre otras).

\section{VIABILIDAD DE LAS ACCIONES OBLICUAS O SUBROGATORIAS EN EL FEDERALISMO FISCAL EN DEFENSA DE LA AUTONOMÍA MUNICIPAL}

Previo a todo examen sobre la extrapolación de las acciones oblicuas o subrogatorias al federalismo fiscal argentino, es necesario llevar a cabo dos estudios. En primer lugar, nos detendremos en el significado y el fundamento legal de este tipo de acciones $y$, posteriormente, analizaremos la legitimación de los municipios en cuestiones de federalismo fiscal.

\section{LA ACCIÓN OBLICUA O SUBROGATORIA}

Entendemos a las acciones oblicuas o subrogatorias como originarias del derecho privado, pero bajo nuestro punto de vista, no existen inconvenientes para llevar a cabo su extrapolación - con las especialidades que el derecho financiero y tributario pueda brindarles- hacia el derecho público, y al federalismo fiscal propiamente dicho.

Llambías (1997) explicaba que la acción subrogatoria es "una facultad conferida a los acreedores, en virtud de la cual ellos pueden gestionar los derechos del deudor que éste deja abandonados" (p. 169). El ámbito de su actuación queda reservado a aquellas situaciones en que una persona no ejercita sus derechos contra sus deudores por motivos tales como la desidia, el desinterés, la imposibili- 
dad material, entre otras ${ }^{1213}$.

$\mathrm{Si}$ analizamos su fundamento, podemos ubicarla en el principio de responsabilidad universal del deudor. Nótese que un simple cambio de los términos "acreedor" y "deudor" -a través del influjo del derecho financiero y tributario- por "nivel de gobierno superior" y "nivel de gobierno inferior" nos permite hablar de responsabilidad en la distribución de recursos en el marco del federalismo fiscal, al tiempo que mantenemos el fundamento de la acción.

En este sentido, señala el catedrático español Montes (1995):

¿Es posible sustraer por entero la acción subrogatoria del principio de la responsabilidad ilimitada del deudor? Difícilmente. Si se permite al acreedor ejercitar los derechos del deudor al objeto, entre otras finalidades, de que pueda cobrar lo que se le debe, pa- rece obvio que un instrumento de ese tipo debe guardar relación con el sistema legalmente establecido de que todo el patrimonio del deudor está afectado al cumplimiento de su débito. (p. 49)

Con respecto a la naturaleza jurídica de la acción, Pizarro y Vallespino (1999) realizan un análisis detallado de las diferentes posturas. Nos permitimos seguir la doctrina de Carnelutti, quien plantea la teoría de la legitimación extraordinaria y expresa que la acción subrogatoria denota la idoneidad de la persona para realizar un acto jurídico eficaz, inferida de su posición respecto al objeto del acto. Continúan explicando los autores antes citados que la formulación distingue la legitimación directa -correspondiente al titular del derecho-, y la legitimación extraordinaria que permite en ciertos supuestos realizar un acto jurídico eficaz sobre una esfera jurídica ajena ${ }^{14}$.

\footnotetext{
${ }^{12}$ Con respecto a las condiciones relativas del deudor, Montes (1995) se expide: "la inercia y solo la inercia del deudor, la circunstancia de que dejen de ejercitarse por su parte, los derechos que le conciernen en el contexto en el que se dibuja la acción subrogatorias es suficiente para que quede expedita la vía de esta, porque el legislador no atiende a vigilar la conducta del deudor en orden a sus derechos, sino a precaver los resultados perjudiciales de la misma en la esfera patrimonial de los acreedores" (p. 151).

${ }^{13}$ En cuanto a la cuestión terminológica, señala Sánchez de Bustamante (1945): "Se dice que es oblicua porque el acreedor, en vista de que el deudor abandona el ejercicio de sus derechos, elimina el inconveniente de su pasividad y actúa en su nombre y lugar cortando al sesgo para alcanzar el fin que se propone; indirecta, por cuanto el acreedor no peticiona en nombre propio, sino en el del deudor y a través de los derechos o del patrimonio de éste, y también porque es un medio subsidiario de hacer ingresar o conservar bienes de ese patrimonio, para recién caer sobre ellos con una acción directa; y subrogatorias porque el acreedor su subroga o sustituye al deudor para obrar en su lugar" (p. 19).
}

${ }^{14}$ En nada se contradice este planteo con la postura de Borda (2008), quien la define como "una acción ejercida por el acreedor por derecho propio, que le ha sido otorgada por ley en forma directa, como que es parte de los remedios concedidos por la ley para obtener el cumplimiento de las obligaciones, todo ello sin perjuicio de que, ante el tercero, el actor accione en nombre y lugar del deudor" (p. 234); ni de Sánchez de Bustamante (1945), quien al avanzar sobre las posturas que ven a la acción subrogatorias como un "mandato" o como una "representación", expresa: "Hemos dicho que la acción oblicua pertenece al acreedor por derecho propio, y ha sido otorgada en forma directa y expresa por la ley, y es parte integrante de los remedios concebidos para obtener el cumplimiento de las obligaciones. Es un atributo inherente al derecho subjetivo, para su protección y defensa utilizable sin necesidad de obtener el consentimiento previo del deudor, ni de solicitar autorización judicial. Pero tiene un doble aspecto [...] 1) Es un derecho propio del acreedor, que ampara su interés personal, facultándolo a poner en movimiento los derechos y acciones del deudor, con el objeto de obtener la tutela del poder público a fin de hacer reconocer y cumplir la pretensión debida al segundo. [...] 2) Frente al tercero el acreedor acción en nombre y lugar del deudor, cuyos derechos invoca y trata de que sean reconocidos" (pp. 101-102). 
Tenemos, entonces, una acción con claro objetivo conservatorio ${ }^{1516}$ que busca una integración del patrimonio del deudor. Es, a su vez, una acción individual e indirecta, en el sentido de que cualquier acreedor puede iniciarla, subrogándose en los derechos del deudor y reemplazándolo en su ejercicio, pero tendrá por efecto que lo conseguido no ingresará directamente a su patrimonio, sino que se dirigirá al patrimonio del deudor originario.

Para analizar los presupuestos de legitimación, es necesario remitirnos a las disposiciones legales de nuestro derecho que receptan esta acción. Originalmente, la acción provenía del Código Velezano que la ubicaba en el art. 1196 como efecto de los contratos, lo que despertaba críticas de la doctrina que planteaba la acción como independiente de la causa que daba vida a la obligación. Hoy, el Código Procesal Civil y Comercial de la Nación Argentina recepta esa doctrina, y ubica a la acción de manera autónoma en el art. 739, capítulo de "obligaciones": "El acreedor de un crédito cierto, exigible o no, puede ejercer judicialmente los derechos patrimoniales de su deudor, si éste es remiso en hacerlo, y esa omisión afecta el cobro de sus acreencias".

De esta manera, podemos observar que cualquier acreedor de manera individual puede ejercer la acción, la legitimación es amplia, solo se requiere como presupuesto un crédito cierto que le dé fundamento, pero sin necesidad de que este sea líquido ${ }^{1718}$. Aunque el Código Procesal Civil y Comercial de la Nación Argentina ${ }^{19}$ establezca que no se requiere para el ejercicio de la acción autorización judicial previa ${ }^{20}$, es cierto que el acreedor subrogante debe demostrar un interés legítimo, que no será otro que la inacción de su deudor, como así también el empobrecimiento o falta de integración del patrimonio del deudor por su inacción.

Señala Sánchez de Bustamante (1945), en torno al interés del acreedor:

La expresión comúnmente usada es la de interés serio y legitimo; frase ecléctica comprensiva de cualquier situación y que claramente da a entender que los acreedores pueden valerse de la acción oblicua solo cuando realmente tienen necesidad

15 Señala Nicoló (1953): "la acción subrogatorias ostenta un cometido exclusivamente conservatorio, en el sentido que representa un medio para asegurar la realización coactiva del derecho de crédito" (pp. 9-10).

${ }^{16}$ No desconocemos la opinión de Borda (2008) quien señala que, en realidad, se trataría de una acción sui generis, no asimilable a las figuras clásicas de medidas conservatorias o ejecutivas.

${ }^{17}$ Es importante aclarar que es indiferente cuál sea el hecho constitutivo del derecho de crédito.

${ }^{18}$ Señala Borda (2008): "No parece razonable exigir que sea líquido en el momento de promover la demanda, si de todos modos es cierto, además, no se duda que esta acción es procedente respecto de obligaciones de dar o hacer, y en estos casos no puede hablarse de deuda liquida. Más dudosa puede resultar la exigencia de la exigibilidad; pero también aquí nos inclinamos por negar que éste sea un requisito indispensable, y por sostener que también los acreedores a término o los condicionales pueden ejercer esta acción, que para ellos desempeñará un importante papel conservatorio" (p. 244).

19 "El ejercicio de la acción subrogatoria que prevé el artículo 1196 del Código Civil no requerirá autorización judicial previa y se ajustará al trámite que prescriben los artículos siguientes" (Código Procesal Civil y Comercial de la Nación, art. 111).

${ }^{20}$ Resulta lógico ya que la vía subrogatorias puede ser utilizada tanto en fase judicial como en la extrajudicial. Messineo (1954) plantea que "el contenido de la subrogación no es necesariamente una acción judicial, pudiendo tratarse de ejercicio de derechos en vía extrajudicial, tal como ocurre con los derechos reales o la interrupción u oposición de la prescripción" (p. 147). 
de actuar, no para molestar inútilmente. 2) El interés nace o puede surgir de una serie variada de hechos relacionados al crédito, a la conducta del deudor y al patrimonio de éste, tanto desde el punto de vista de su solvencia como de los derechos susceptibles de ejercicio [...] c) Además el interés debe poder ser apreciado desde el punto de vista de su finalidad práctica. [...] 3) Indudablemente el interés de quien pretenda ejercer cualquier acción debe concretarse en una utilidad. [...] El art. 1196 C.C reconoce al acreedor el derecho de poner en actividad los derechos y acciones de su deudor: este poder no es otra cosa que la protección de su interés, consisten en la facultad de realizar los actos necesarios para obtener el cumplimiento actual o futuro de la prestación. En consecuencia, basta exponer esa razón dando los motivos que obligan a obrar, para que proceda la demanda si prima facie se encuentran reunidas las condiciones fundamentales a ese efecto. (pp. 329-332)

En este sentido, Montes (1995), refutando cualquier postura que refiera a la necesidad de demostrar la insolvencia del deudor subrogado, explica:

El interés del acreedor en actuar vendría impuesto por la prudencia ante el temor de que pudiera sufrir quebranto su dere- cho por la desatención patrimonial que su deudor muestra, y así todo quedaría reducido a un estado precautorio que se pone en marcha para evitar males futuros y para prevenir que el acreedor pueda llevarse la desagradable sorpresa, a la hora de que intente la realización de su derecho, de que el patrimonio del deudor carece de las fuerzas precisas para atender de manera cumplida semejante realización. (p. 140)

Por otro lado, los cuerpos legales argentinos mencionados se detienen a señalar la obligación de citar al deudor subrogado para que comparezca al juicio respectivo, ya sea para formular oposición a la acción del acreedor subrogante, o para decidir actuar e interponer demanda contra sus deudores ${ }^{21}$.

Ahora bien, con respecto a los efectos de la acción oblicua o subrogatoria, se produce una subrogación procesal, puesto que el acreedor subrogante actúa en representación ajena, pero con interés propio en un proceso con el objeto de ejercitar los derechos del deudor subrogado frente a sus acreedores, a fin de integrar su patrimonio para luego satisfacer su acreencia con este. No debemos perder de vista que el acreedor subrogante no es titular del crédito que reclama por vía oblicua, por lo cual, la acreencia ingresará no a su patrimonio, sino al del deudor subrogado, siempre recordando que se trata de una acción meramente conservatoria ${ }^{22}$.

\footnotetext{
21 "A antes de conferirse traslado al demandado, se citará al deudor por el plazo de DIEZ (10) días, durante el cual éste podrá: 1) Formular oposición, fundada en que ya ha interpuesto la demanda o en la manifiesta improcedencia de la subrogación. 2) Interponer la demanda, en cuyo caso se le considerará como actor y el juicio proseguirá con el demandado" (Código Procesal Civil y Comercial de la Nación, art. 112).

${ }^{22}$ De esta forma podemos ver que el éxito de la acción oblicua o subrogatorias favorecerá a todo acreedor del deudor subrogado, en atención a que este verá integrado su patrimonio, prenda común de todos sus acreedores. En este sentido, Sirvent García (1997) expresa: "cuando el acreedor ejercita la acción subrogatorias se coloca en la posición que como acreedor tiene su deudor frente al tercero, debiéndole reclamar lo que este adeude. El resultado de esta reclamación pasará al patrimonio del deudor, y solo después podrá actuar el acreedor contra los bienes
} 


\section{LOS MUNICIPIOS Y LA LEGITIMACIÓN ACTIVA}

El respeto al federalismo guía la construcción de nuestro régimen de coparticipación, cuyo eje troncal se encuentra en la Ley $\mathrm{N}^{\circ}$ 23.548, más aún luego de la reforma constitucional de $1994^{23}$. El federalismo no es una dádiva que reciben las provincias de la Nación, ni tampoco representa la puja permanente de los recursos por una mejor distribución, tal como afirmó el senador por corrientes Romero Feris, en la novena reunión de la 51 sesión ordinaria de la Honorable Cámara de Diputados (26 y 27 de junio de 1988). El federalismo es el faro detrás de extensos debates que llevaron a crear el régimen actual, con la deficiencia temporal de no contemplar la condición autonómica de los municipios, ya que para 1988 reinaba la concepción autárquica del ente municipal. No obstante, a raíz de la reforma constitucional de 1994, es necesario interpretar constitucionalmente el régimen de coparticipación, de una manera armónica y en consonancia con la autonomía municipal garantizada.

La nueva categoría en que se sitúa al municipio desde la reforma constitucional de 1994 exhorta a una interpretación del federalismo fiscal que respete la trilogía de poder y que otorgue a los municipios una voz fuerte en la materia. No obstante, sin los mecanismos de defensa necesarios, la voz se diluye, y da paso al vaciamiento de su autonomía.

Creemos conveniente receptar la legitimación de las acciones oblicuas tal como fueron diagramadas, con el objeto de superar aque- llas situaciones donde los medios actuales se vuelven inconsistentes ante la pasividad de los estados provinciales, al menos, hasta que se logre el consenso político para alcanzar una nueva ley de coparticipación donde se le dé participación a este nivel de gobierno olvidado.

Resulta necesario analizar la legitimación de los estados municipales en cuestiones de federalismo fiscal para dar peso argumentativo a la utilización de las acciones oblicuas ante las situaciones planteadas anteriormente. Párrafos atrás, señalamos que el interés que sustentaría la legitimación activa municipal a dichas acciones se encuentra en el desinterés o la pasividad del nivel de gobierno provincial ante situaciones de violación del régimen de federalismo, lo cual deja al municipio en el desamparo fiscal y financiero.

No obstante, fuera del ejercicio de las acciones oblicuas que planteamos como viable, la materia de federalismo fiscal pareciera encontrarse fuera del alcance de los municipios. Para explicar esto, notemos que el art. 75 inc. 2 de la Constitución Nacional, al establecer el procedimiento para la sanción de una nueva ley de coparticipación, determina que esta debe provenir o ser fruto de "una ley convenio, sobre la base de acuerdos entre la Nación y las provincias", para acto seguido señalar entre quiénes se distribuirá la masa: "La distribución entre la Nación, las provincias y la ciudad de Buenos Aires y entre éstas, se efectuará...." Por lo cual, no se hace referencia a los municipios ni en la creación de la ley ni en la distribución pese a su autonomía reconocida por el art. 123.

\footnotetext{
recuperados" (p. 45).

${ }^{23}$ Lo cierto es que la ley de necesidad de reforma constitucional № 24.309 habilitó a la convención constituyente que se conformaría a tratar el tema de la distribución de competencias entre la Nación y las provincias respecto de la prestación de servicios o en materia de gastos y recursos y, dentro de este y especialmente, el de coparticipación federal. Estos puntos se ubicaban bajo el título "Fortalecimiento del Régimen Federal", cuestión no soslayable. Asimismo, se habilita el debate sobre la incorporación de la autonomía municipal.
} 
Por otro lado, en la ordenanza procesal de la Comisión Federal de Impuestos, el municipio no alcanza el carácter de parte, más bien, se lo recepta como posible coadyuvante. La condición de parte sustancial continúa siendo para Nación y provincia," por ser las partes contratantes del régimen".

Sectores de la doctrina consideran que el municipio no debe ser tenido como un sujeto de coparticipación, sencillamente porque la propia Constitución Nacional los omite en el art. 75 inc. 2 y, por lo tanto, toda ley que así los recepte será inconstitucional por ir en contra de la carta magna. En este sentido, Pérez Hualde (1999) señala:

La calidad de sujeto que puede imponer contribuciones conforme a la Constitución convierte al municipio en un partícipe necesario en el debate tendiente a la coordinación y racionalización de las cargas impositivas, pero de ningún modo lo convierte en sujeto del propio acuerdo federal que implica la ley convenio que prevé el art. 75 inc2. (p. 29)

Desde nuestra perspectiva, sostenemos que el municipio ha elevado su estatus sin desmedro alguno de las provincias. La autonomía garantizada por el art. 123 determina un reconocimiento a la trilogía del poder, lo cual refuerza su posición en la estructura federal. Por lo tanto, el federalismo fiscal argentino evoluciona al incorporar nuevos sujetos ${ }^{24}$.

Por otro lado, es la propia constitución en el art. 75 inc. $30^{25}$ la que les reconoce poder tributario, presupuesto básico del concepto de autonomía que sostenemos, lo que vuelve a traer el ideario federal de unión nacional a la mesa de discusión, ante la cual es necesaria una coordinación y armonización del poder tributario para un mejor despliegue de dicho poder sin solapamientos.

Pero no solo debemos quedarnos con la realidad normativa. En los hechos, resulta que el municipio termina siendo un beneficiario directo de la coparticipación federal, aunque no se encuentre en el texto constitucional a la hora de la distribución. Esto ocurre, sencillamente, por las siguientes cuestiones:

1) Primeramente, porque es la propia ley de coparticipación № 23.548 la que establece como obligación de las provincias establecer un "un sistema de distribución de los ingresos que se originen en la Ley [23.548] para los municipios de su jurisdicción" (art. 9, inc. g). Por lo cual, en última instancia, es la propia ley la que reconoce, o bien, erige a los municipios como beneficiarios de los recursos. La calidad de beneficiarios en primera o segunda instancia no cambia la cuestión.

2) La situación actual de desfinanciamiento estructural de los municipios originada en la imposibilidad fáctica de crear impuestos dado al concepto técnico de prohibición de analogía- y la ausencia de fuentes tributarias libres determinan que el municipio subsiste de su calidad de beneficiario de los fondos coparticipables, nacionales y provinciales.

3) Es ilógico, irrazonable y, a todas luces,

\footnotetext{
${ }^{24}$ No desconocemos doctrinas que opinan que la consagración de la autonomía municipal viene a reforzar la presencia del municipio en la relación federal, más no a título directo, sino a través de las provincias a las cuales se adscriben, por tal razón no se incluyen en la distribución de la coparticipación según la carta magna. Para profundizar acerca de este asunto, véase Ábalos (2013).

25 "Las autoridades provinciales y municipales conservarán los poderes de policía e imposición sobre estos establecimientos" (Constitución de la Nación Argentina, art. 75, inc. 30).
} 
contrario a la autonomía municipal que se impongan obligaciones a los municipios por intermedio de las provincias, sin instaurarlos como beneficiarios directos de la coparticipación ${ }^{26}$.

Para apoyar nuestra postura, citamos la opinión de Garat (2009a):

A partir de la reforma de 1994, con el reconocimiento de la autonomía municipal y la adopción formal del sistema de coparticipación federal los municipios, incluidos como beneficiarios de la distribución en el actual régimen transitorio de la Ley 23.548 , deberían continuar siéndolo en la futura ley convenio, ya no sólo porque lo dispongan sus respectivas Constituciones Provinciales (cuando ello así ocurre) sino como consecuencia de la elevación de su "status" constitucional. (p. 54)

En definitiva, no existen inconvenientes hoy en día ni en el aspecto normativo ni en el terreno fáctico para situar al municipio en pie de igualdad para discutir la materia de federalismo fiscal. Aunque reconozcamos que la trilogía de poder enmarcada en la Constitución Nacional desde la reforma no determina igualdad de competencias, facultades $y$, en definitiva, poder entre dichos niveles, nada obsta a que el municipio, al respetar las relaciones de subordinación, discuta con su provincia cuestiones de su interés para que, luego, sea la provincia quien los traslade como interlocutor ante el estado nacional.

Esta interpretación que postulamos es la que debe guiar el régimen de coparticipación actual y el próximo a dictarse en cumplimiento de la manda constitucional y, a la postre, determinará y legitimará a los municipios a reclamar cualquier tipo de afectación capaz de repercutir en su financiamiento.

\section{VIABILIDAD DE LA EXTRAPOLACIÓN DE LA ACCIÓN OBLICUA AL DERECHO PÚBLICO}

Los problemas de inconsistencia originados en los procedimientos establecidos positivamente, y que no permiten dar una respuesta satisfactoria en casos de pasividad provincial frente a las alteraciones unilaterales al régimen troncal de federalismo fiscal, son argumentos a favor de la utilización de acciones oblicuas en la materia:

1) Las singularidades propias del derecho financiero permiten adoptar este tipo de acciones nacidas en el marco del derecho privado sin ningún inconveniente, lo cual permite una adaptación total al derecho público, sin des-

\footnotetext{
${ }^{26}$ No obstante, debemos hacer notar, tal como lo sostiene Spisso (2018), que es impensable lograr un acuerdo si los compromisos que asumen las provincias no obligaran a sus municipios, convenio que no tendría, por otra parte, razón de ser si el propósito esencial de evitar la superposición de tributos sobre una misma fuente pudiese ser soslayado impunemente por los Estados municipales. No ha de verse, entonces, en tales exigencias emanadas de los pactos fiscales un desconocimiento de la autonomía municipal, salvo supuestos de desviación de poder en los que se pretenda privar a los municipios de los recursos mínimos indispensables para desempeñar sus cometidos, circunstancia excepcional que en su caso deberá probarse debidamente (véase Spisso, 2018). En el mismo sentido Garat (2009b) reflexiona: "¿pueden las provincias obligarse por sus municipios autónomos? Pensamos que la respuesta es afirmativa en tanto ello se produzca sin afectar la esfera de autonomía en materia tributaria que cada Constitución provincial reconozca a sus municipios. Pero además, aun cuando ese ámbito de autonomía constitucional sea invadido por el contrato federal tributario, no se afectarán efectivamente los derechos de los municipios mientras éstos consientan tal estado de cosas tácitamente, sea por acción (recibir los fondos distribuidos o cumplir las obligaciones que les son impuestas) o por omisión (abstenerse de cumplir las obligaciones a su cargo)" (p. 104).
} 
medro de la naturaleza jurídica y fundamento de la acción. En nada impide este accionar la consideración de no autonomía del derecho financiero. En palabas de Espeche (2016):

Consideramos que el hecho de que el derecho financiero no sea una rama jurídica autónoma en modo alguno pone en luto o en un plano inferior a esta disciplina jurídica; por el contrario, es su especial característica singular, que requiere el verdadero conocimiento de todo el derecho para adentrarse en las particulares características de complejidad que posee, que lo hace una disciplina jurídica excepcional, viva y dinámica que exige necesariamente su estudio didáctico especializado. (p. 79)

2) Nada impide modificar terminológicamente los sujetos procesales en la respectiva acción; esto es, deudor subrogante = nivel de gobierno subrogado, acreedor subrogante $=$ nivel de gobierno subrogante. Dichas modificaciones en los sujetos no alteran la relación jurídica inherente a la acción respectiva. Nótese que en todos los casos un nivel de gobierno actuará en representación ajena, pero con interés propio en un procedimiento contra un tercero - con calidad de nivel de gobierno-, de igual forma que contra un tercero deudor de su deudor.

3) La extrapolación al derecho financiero en nada afecta al fundamento de la acción ubicado en el principio de responsabilidad universal. En este sentido, veamos que la ley troncal del sistema № 23.548 garantiza, por influjo de la reforma constitucional de 1994, la integridad de la masa coparticipable, sumado a que el máximo tribunal ha dispuesto la imposibilidad de modificar el régimen de manera unilateral, como fue señalado.

La acción permite aumentar la garantía de integridad del sistema de coparticipación, que en definitiva distribuye los recursos de los cuales hoy se nutren y subsisten los municipios de argentina. Es importante tener presente que es la propia ley de coparticipación la que establece como obligación de las provincias "diagramar un sistema de distribución de los ingresos que se originen en esta Ley para los municipios de su jurisdicción" (Ley №23.548, art. 9, inc. g).

4) El carácter conservatorio de la acción oblicua tampoco se ve afectado mediante la extrapolación al derecho financiero, toda vez que, en definitiva, lo que el nivel de gobierno subrogante buscará es integrar el "patrimonio". Más específicamente, busca integrar el arca fiscal del nivel de gobierno superior que representa, al denunciar las violaciones o las irregularidades que afectan a la masa coparticipable, lo que en definitiva permitirá tener garantizado una distribución de recursos integral hacia su persona.

5) La acción no perderá sus caracteres de "individual", ya que cualquier municipio como nivel de gobierno inferior puede entablarla y representar así al superior provincial, e "indirecta", en tanto el municipio como nivel de gobierno inferior representará procesalmente a la provincia como nivel de gobierno superior en los reclamos por violaciones al régimen producidos por Nación. Estas violaciones producen un deterioro en los fondos a recibir por la provincia y, en definitiva, repercute en lo que el municipio recibirá mediante mecanismo de coparticipación provincial. Por último, la acción tampoco perderá su característica "facultativa", puesto que ningún municipio se encontrará obligado a entablarla.

6) En cuanto a la legitimación activa, notamos que no se produce modificación sustancial alguna con la extrapolación de la acción al derecho financiero, en tanto siempre tendremos en sustancia un acreedor subrogante; como dijimos, nada dificulta modificar termi- 
nológicamente al sujeto por nivel de gobierno subrogante. Este último (debido a la estructura del sistema de coparticipación vigente en nuestro país y la obligación que pesa sobre las provincias de establecer un mecanismo de distribución de recursos hacia sus municipios) pasa a tener la calidad de acreedor. Lógicamente, no en el sentido del derecho privado, aunque mantiene ciertas particularidades que lo asemejan. Es decir, el municipio se encuentra legalmente instituido como beneficiario de estos recursos en última instancia, por lo tanto, tiene derecho a ellos, los cuales la provincia no puede desconocer ${ }^{27}$.

De esta manera, el municipio tiene un "crédito" contra la provincia, según las particularidades propias del derecho financiero y con el término adaptado a dicho rama del ordenamiento jurídico. Razonablemente, dicho "crédito" no tendrá la consideración de líquido o exigible, porque en definitiva eso dependerá de que ingrese al mecanismo de coparticipación provincial, pero dado el carácter conservatorio de la acción, nada impide que se la utilice para créditos de esta naturaleza.

7) En cuanto al interés legítimo que respalda la legitimación activa, este queda demostrado ante las innumerables ocasiones donde la provincia no ejercita sus derechos de reclamo ante violaciones al federalismo fiscal por parte del Estado Nacional. En definitiva, esto afecta la integridad de la masa coparticipable, lo cual repercute en los recursos a recibir que ingresarán al mecanismo de coparticipación provincial hacia sus municipios. Esta omisión de la provincia puede darse por desidia, desinterés, cuestiones políticas, acuerdos por obras, y demás causas. Dicha inercia justificaría en todo sentido la utilización de la subrogación procesal mediante la acción que planteamos.

8) Dado a que, en definitiva, el nivel de gobierno inferior (el municipio, como proponemos) no es titular del "crédito" de la provincia contra el Estado Nacional (encargado de recaudar y distribuir los recursos en el marco de la coparticipación federal), no podrá disponer de manera alguna de él. En todo caso, ejercitada la acción con éxito, el "crédito" ingresará a las arcas fiscales de la provincia, para recién luego integrar la coparticipación provincial que determinará los recursos al municipio como nivel de gobierno subrogante.

9) La extrapolación de la acción oblicua o subrogatoria al derecho financiero de ninguna manera modifica la relación jurídica entre provincia y Nación, inherente a la particularidad de "federalismo de concertación" estructurado bajo leyes-convenio. El municipio subrogante no viene a afectar la estructura federal, ni a constituirse como un sujeto federal no incluido en el art. 75 inc. 2 de la Constitución Nacional. La acción solo produce una sustitución meramente procesal, de igual forma, tampoco otorga privilegio alguno al municipio que facultativamente decide entablar la acción respectiva. Cualquier éxito en esta beneficiará a los demás municipios ya que el "crédito" de provincia contra Nación se incorporará a sus arcas fiscales $y$, en definitiva, integrará la coparticipación provincial, según los porcentajes correspondientes.

10) La obligatoriedad de citar al deudor subrogado $=$ nivel de gobierno subrogado $=$ provincia al procedimiento una vez entablada

\footnotetext{
${ }^{27}$ Recordamos las palabras de Frías (1970): “negociar, aquí, es aproximar las bases empíricas a las bases teóricas, la realidad a la Constitución. Es también aludir a los sujetos de la negociación: El Estado federal y las provincias, por una parte, provincias y municipios por otro. Las provincias tienen que reivindicar de la Nación ciertos poderes económicos y políticos que les pertenecen. A su vez el municipio, en su orden propio, es acreedor de las provincias argentinas" (p. 62).
} 
la acción no se imposibilita en absoluto, más bien resulta lógico y provechoso, ya que en todo momento la provincia podrá tomar posición y ejercer sus derechos respectivos contra un Estado Nacional que violenta el régimen convenido. Dicho actuar de la provincia determinará la cesación de la acción por ausencia del presupuesto de inactividad del subrogado, pero de manera alguna supone retrotraer actuaciones ya efectuadas.

11) Respecto a los procedimientos ante la Comisión Federal de Impuestos en el marco de la ley № 23.548 y demás instrumentos del federalismo de concertación, la Ordenanza Procesal bajo Resolución Plenario № 91/2004 establece como de aplicación supletoria para todo lo no expresamente regulado y que no se oponga a su letra el Código Procesal Civil y Comercial de la Nación Argentina ${ }^{28}$. Ante la no regulación de las acciones oblicuas o subrogatorias en la ordenanza procesal se habilita, por lo tanto, la aplicación supletoria de lo regulado en el código de procedimiento respecto a dichas acciones.

Nótese que en ninguna medida la regulación que hace el Código Procesal Civil y Comercial de la Nación Argentina se opone a lo establecido por la Ordenanza Procesal. Alguien puede decir que una remisión supletoria colocaría al municipio en un estadio sustancial de "parte" en el marco del federalismo fiscal, cuestión que se opone al art. 4, que establece que las municipalidades pueden acceder al rango de coadyuvantes, pero nunca de parte ${ }^{29}$. No obstante, la supuesta oposición es solo aparente. Lo que la acción subrogatoria produce es una mera sustitución a nivel procesal, de ninguna manera modifica la condición sustancial de la relación jurídica originaria que nace en el marco de las leyes-convenio entre provincia y Nación.

\section{ÁMBITO DE APLICACIÓN DE LA ACCIÓN OBLICUA EN EL MARCO DEL FEDERALISMO FISCAL}

Resta definir si nuestra investigación plantea la utilización de las acciones oblicuas en el procedimiento administrativo ante la Comisión Federal de Impuestos o ante el Poder Judicial.

Respecto del primero, manifestamos que no habría ningún inconveniente para su utilización, más bien es absolutamente necesario brindar mayores facultades de acción a los entes más desprotegidos del federalismo fiscal ante situaciones de pasividad e inacción de la provincia no contemplados por su Ordenanza Procesal. Creemos conveniente y recomendable que los municipios se dirijan a la Comisión ante estas situaciones, siempre que no pierdan

\footnotetext{
28 "La tramitación de las causas que, conforme a las leyes 20.221 y 23.548, compete sustanciar a la Comisión Federal de Impuestos, se ajustará a las disposiciones de la presente Ordenanza Procesal. Regirán con carácter supletorio, en cuanto no se opongan a los preceptos de las leyes citadas y a la presente, los siguientes ordenamientos en el orden en que se los menciona: el Reglamento de la Comisión Federal de Impuestos, el Código de Procedimientos en lo Civil y Comercial de la Nación, y la Ley Nacional de Procedimientos Administrativos" (Comisión Federal de Impuestos, Resolución Plenario $\mathrm{N}^{\circ} 91 / 2004$, art. 1).

29 “Podrán asumir la condición de parte en el proceso los fiscos contratantes, los contribuyentes y las asociaciones reconocidas, en cuanto resulten afectados. Comisión Federal de Impuestos Las Municipalidades y los organismos nacionales o provinciales, autárquicos o no, de los que hayan emanado gravámenes cuya compatibilidad con el régimen de coparticipación se controvierta, deberán ser notificados debidamente de todo trámite que los afecte a fin de que puedan intervenir como coadyuvantes si lo estiman oportuno, pero aún cuando serán tenidos en cuenta en toda la sustanciación de la controversia, no adquirirán la categoría de partes en el proceso, la que únicamente, y en todos los casos, seguirá perteneciendo en exclusividad a la Nación o a la Provincia, respectivamente, por ser las partes contratantes" (Comisión Federal de Impuestos, Resolución Plenario Nº1/2004, art. 4).
} 
de vista que las resoluciones de la Comisión, como autoridad de aplicación del régimen, son obligatorias para provincia y Nación. Para ello, exhortamos una modificación a la ordenanza procesal del citado organismo, a fin de receptar la viabilidad de tales acciones, aunque reconocemos que por aplicación supletoria del código ritual deberían aceptarse.

Debe reconocerse que dicho organismo, ante situaciones ajenas al procedimiento de dictado de tributos análogos a los coparticipados, disminuye sus posibilidades de acción en cuanto a sanciones aplicables. La Ley № 23.548 establece la competencia de la Comisión para ordenar al Banco de la Nación que se abstenga de transferir al fisco sancionado los importes que le correspondan sobre lo producido del impuesto a distribuir análogo al tributo impugnado, hasta que se dé cumplimiento a la decisión del organismo, pero no recepta ninguna otra sanción posible de aplicar en procedimientos por violación unilateral o irregularidades en el régimen.

Del mismo modo, se reconoce la ausencia de facultades jurisdiccionales a la Comisión Federal de Impuestos para decretar medidas cautelares ante hechos de violación o modificaciones unilaterales al régimen por parte de Nación. De esta forma, obliga prácticamente a los estados provinciales a recurrir al Poder Judicial, que genera los siguientes inconvenientes:

1) Si se decide recurrir a la Corte Suprema de Justicia vía recurso extraordinario ante la Comisión Federal de Impuestos, luego de la resolución del Plenario de Representantes en base a la Ley No 14, encontramos los obstáculos generados por el constante cierre de la competencia por parte del máximo tribunal, que desde el fallo "Transportes Automotores Chevallier" (CSJN, 1994, Fallos, 310:2092) viene sosteniendo. e-ISSN 2618-4699
2) Si se decide iniciar la causa de manera autónoma, encontramos el cierre de la competencia originaria en cuestiones de coparticipación que la Corte Suprema viene sosteniendo desde el precedente "Papel Misionero" (CSJN, 2009, Fallos, 332:1007), que obliga a las provincias a recurrir a los tribunales provinciales $y$, oportunamente, recurrir al máximo tribunal vía recurso extraordinario.

3) En cuestiones que surgen de Pactos Fiscales y demás instrumentos de política financiera, la Corte Suprema de Justicia ha sostenido un criterio dispar a la materia que surge de la ley de coparticipación, en ocasiones cierra su competencia originaria y deriva a las provincias a los tribunales provinciales. Así lo ha establecido en fallo "Centauro SA" (CSJN, 1995, Fallos, 318:2551) y “Matadero y Frigorífico Merlo" (CSJN, 2004, Fallos, 326:880).

No obstante, el ya mencionado fallo "Santa Fe c/Estado Nacional" (CSJN, 2015, Fallos, 538:2009), abre una nueva puerta a la competencia originaria particularmente a los supuestos de modificaciones o violaciones unilaterales al régimen del federalismo fiscal. En este sentido, retomamos la posibilidad de la utilización de acciones oblicuas, no solo en instancias provinciales sino también ante el máximo tribunal por parte de los municipios.

Como sustento argumental a favor de la utilización de este tipo de acciones en el marco de la coparticipación en el Poder Judicial de la Nación, traemos a colación el fallo "Mesa Nacional de Jubilados, Pensionados y Retirados c/PEN" dictado por la jueza en lo contencioso administrativo federal № 10. Dicha causa se origina en una acción oblicua presentada por la Mesa de Jubilados y Pensionados que solicita cautelarmente la suspensión del decreto de necesidad y urgencia № 2635/2015 de la otrora presidenta Cristina Fernández de Kirchner, por el cual se 
hacía extensivo el fallo "Santa Fe" (CSJN, 2015, Fallos, 538:2009) a las demás provincias, y se les devolvía la detracción del $15 \%$ que estaba destinado a la financiación de la ANSES.

Del mismo modo, tenemos el planteamiento judicial del Municipio de Villa Gesell contra el Estado Nacional, ante el Juzgado Federal de 1 ra Instancia de Dolores, provincia de Buenos Aires, actualmente en curso, donde se sostiene la inconstitucionalidad de decretos de necesidad y urgencia № 561/19 y el 567/19 de finales de 2019, atentos a modificar impuestos coparticipables de manera unilateral con clara afectación de la integridad de la masa coparticipable.

\section{CONCLUSIONES}

La realidad actual nos muestra a los estados municipales inmersos en una crisis que, a la par de económica, reconoce como fuente principal el aspecto financiero. Particularmente, la imposibilidad de crear fácticamente sus propias fuentes repercute en las competencias y las funciones que tiene atribuidas.

Así, queda expuesta la poca trascendencia que los municipios tienen en el entramado de nuestro sistema federal, donde no tienen ni voz ni voto en aquellos acuerdos suscriptos entre provincia y Nación, muchos de ellos que afectan su poder tributario como expresión de la autonomía que se le garantiza. La provincia celebra acuerdos con Nación donde asume obligaciones en nombre de sus municipios, lo cual es una muestra de la baja importancia que se le da a este nivel de gobierno.

Las constantes violaciones a los acuerdos en la materia repercuten en la masa a coparticipar que, en definitiva, financia a los municipios. Asimismo, en caso de no ser denunciadas estas irregularidades por las provincias, sitúan al Estado Nacional en una posición de supremacía total con respecto a los estados subnacionales y profundiza la crisis de los municipios como nivel de gobierno más desprotegido.

Dada la falta de voluntad política de lograr consensos y así cumplir con la manda constitucional de sancionar una nueva ley de coparticipación, que deberá necesariamente contemplar la situación de los gobiernos municipales, es necesario brindarles a estos últimos las armas necesarias para defender su posición de importancia en el sistema federal. En este sentido, las acciones subrogatorias, tal como las entendemos, son un mecanismo viable atento a la dificultad de lograr consensos superiores capaces de alcanzar una nueva la ley de coparticipación que reemplace la actual, sancionada antes del reconocimiento constitucional de la autonomía municipa ${ }^{30}$.

La extrapolación de este tipo de acciones que nacen en el derecho privado (con las particularidades que el derecho público, en especial, el derecho financiero y tributario puede atribuirles) es una realidad no contemplada, pero que en nada desnaturaliza la acción. La situación de un acreedor que no procede a defender sus derechos contra sus deudores puede asemejarse a la situación del nivel de gobierno provincial que no procede a denunciar los recortes unilaterales que desde Nación se producen.

El Estado Nacional parece jugar con el déficit de las arcas provinciales, las mantiene en un federalismo perverso donde las principales fuentes tributarias se concentran en el estado central, lo cual hace muy difícil -y, tal vez, impensado-que las provincias denuncien la ley de coparticipación para recuperar sus potestades tributarias.

\footnotetext{
${ }^{30}$ Recordemos que la actual ley de coparticipación federal de impuestos № 23.548 fue sancionada el 7 de enero de 1988 , mientras que el reconocimiento de la autonomía municipal se alcanza con la reforma constitucional de 1994.
} 
El problema es que no denunciar, o bien, desistir de las acciones oportunamente presentadas significa mantener un status quo violatorio del más puro federalismo fiscal, lo cual afecta la masa coparticipable que en última instancia recae en los municipios como los entes más desprotegidos. Estos últimos no fueron llamados a expresar su opinión en torno a las obligaciones que las provincias asumen a la hora de formar parte del régimen.

Más aún, su imposibilidad fáctica de crear impuestos con que financiarse los hace dependientes de transferencias de niveles de gobierno superiores y sumamente vulnerables ante los cambios en las reglas de juego que las operaciones entre provincia y Nación producen. El resultado decanta por necesidad, y no es más que la creación de impuestos disfrazados por tasas retributivas de servicios que en nada respeta las condiciones establecidas en la doctrina judicial (CSJN, 1989, Fallos, 1312:1575 y 2008, Fallos, 332:1503).

Por consiguiente, es crucial receptar nuevos mecanismos de acción en defensa de un federalismo cada vez más unitario, que proteja a los estados municipales que, a pesar de su autonomía garantizada, en los hechos parece vaciarse de contenido, entre otras cuestiones en materia de financiación propia y suficiente.

Lamentablemente, la falta de concesos políticos y los egoísmos siguen imposibilitando el dictado de una nueva ley de coparticipación que, entre otras cuestiones, reconozca la autonomía municipal y las consecuencias que de ella se derivan, dando voz a los municipios. Esto no supone que se les consulte de manera directa, puede razonablemente ser un proceso indirecto o en dos etapas, primariamente con su provincia, para que sea esta quien traslade a los futuros acuerdos con el Estado Nacional la postura o la opinión municipal.

Debemos reconocer que actualmente exis- te un vacío o una laguna jurídica en torno a un hecho de reconocida trascendencia como lo es la falta de denuncia o reclamo por parte de las provincias a las violaciones al régimen del federalismo fiscal por parte de la Nación. Del mismo modo, los mecanismos legales de defensa establecidos en la propia ley de coparticipación, y que se encuentran procedimentalmente receptados en la ordenanza procesal de la Comisión Federal de Impuestos, demuestran una inconsistencia clara al no dar respuesta a las situaciones omisivas planteadas.

En definitiva, las acciones oblicuas serán no solo un medio idóneo para defender nuestro federalismo fiscal de embates unilaterales inconstitucionales, sino también un medio para fortalecer institucional y políticamente tanto a los estados municipales como también a los gobiernos provinciales mediante un trabajo mancomunado en el reclamo de recursos que se consideren injustamente distribuidos.

\section{REFERENCIAS BIBLIOGRÁFICAS}

Ábalos, M. G. (2013). Facultades delegadas y potestades tributarias provinciales. Especial referencia a la prescripción de tributos locales. Estudios de Derecho Público. Asociación de Docentes de la Facultad de Derecho y Ciencias Sociales de la UBA. Buenos Aires.

Bertea, A. O. (2010). Financiación de provincias y municipios: nuevo paradigma del federalismo fiscal argentino, en Tributación Local Provincial y Municipal, dirigido por Juan Manuel Álvarez Echagüe, 1er. edición, Editorial Ad Hoc.

Bertea, A. O. (2011). Pacto Fiscal: cumplimiento asimétrico. [Entrada de blog]. Recuperado de http://federalismofiscal.com/1500-2/ [23/6/2020].

Bertea, A. O. (2016). Asignación específica de impuestos coparticipables: ¿peligra 
la vigencia del impuesto al cheque? [Entrada de blog]. Recuperado de http:// www.federalismofiscal.com/wp-content/ uploads/2016/10/Asignaciones-especificas.pdf [18/10/2018].

Borda, G. A. (2008). Tratado de Derecho Civil. Obligaciones. Buenos Aires: La Ley.

Bulit Goñi, E. G. (1995). La Coparticipación Federal en la reforma constitucional de 1994. Revista La Ley, T. 1995-D. Sec. Doctrina. Buenos Aires: La Ley.

Bulit Goñi, E. G. (2003). Sistemas de Coordinación de potestades tributarias a distintos niveles de gobierno en el régimen federal argentino. En García Belsunce. Horacio A. (Coord.). Tratado de tributación. Buenos Aires: Astrea.

Casás, José Osvaldo (1996). El laberinto de la Coparticipación, Periódico Económico Tributario PET No 107. Buenos Aires: La Ley.

Código Procesal Civil y Comercial de la Nación Argentina. Boletín Oficial de la República Argentina. Ciudad de Buenos Aires, Argentina. 1 de febrero de 1968. Recuperado de http:// servicios.infoleg.gob.ar/infoleglnternet/ anexos/15000-19999/16547/texact.htm

Comisión Federal de Impuestos. Resolución General Interpretativa No 10/1992. 18 de septiembre de 1992. Recuperado de http:// www.cfi.gov.ar/docs/resoluciones/rgi/ r_g_i_n_10_1992.pdf

Comisión Federal de Impuestos. Resolución Plenario $N^{\circ}$ 91/2004. 4 de marzo de 2004. Recuperado de http://servicios.infoleg.gob.ar/infoleglnternet/ anexos/90000-94999/93525/norma.htm

Constitución de la Nación Argentina. Boletín Oficial de la República Argentina. Ciudad de Buenos Aires, Argentina. 3 de enero de 1995. Recuperado de http://servicios.infoleg.gob.ar/infolegInternet/anexos/0-4999/804/norma.htm
Convención Nacional Constituyente. (9 de agosto de 1994). Diario de sesiones taquigráficas de la 27 reunión de la $3^{\text {ra }}$ sesión ordinaria (continuación). Recuperado de https://www.senado.gob.ar/parlamentario/convenciones/descargarDiario2/29

CSJN. (21/11/1958). Madariaga de Anchorena, Carlos Juan s/Demanda de inconstitucionalidad. Fallos, 242:280.

CSJN. (5/9/1989). Cia. Química SA c/ Municipalidad de Tucumán. Fallos, 1312:1575.

CSJN. (17/11/1994). Transportes Automotores Chevallier S.A. c/resolución $n^{\circ} 21$ del Plenario de la Comisión Federal de Impuestos s/ Impugna imp. a los ingr. brutos locales. Fallos, 310:2092.

CSJN. (19/12/1995). Centauro SA c/Provincia de Buenos Aires. Fallos, 318:2551.

CSJN. (22/4/1997). Asociación de Grandes Usuarios de Energía Eléctrica de la República Argentina (AGUEERA) c/Buenos Aires, Provincia de y otros/ acción declarativa. FaIlos, 322:1781.

CSJN. (7/12/2001). El Cóndor empresa de transportes S.A. c/Buenos Aires, Provincia de s/acción declarativa. Fallos, 324:4226.

CSJN. (27/5/2004). Matadero y Frigorífico Merlo SA c/Provincia de Buenos Aires. Fallos, 326:880.

CSJN. (25/11/2008). Laboratorios Raffo SA c/ Municipalidad de Córdoba. Fallos, 332:1503.

CSJN. (5/5/2009). Papel Misionero S.A.I.F.C. c/ Misiones, Provincia de s/acción declarativa. Fallos, 332:1007.

CSJN. (24/11/2015). Provincia de Córdoba c/ Estado Nacional y otros/medida cautelar. Fallos, 786:2013.

CSJN. (24/11/2015). Provincia de San Luis c/ Estado Nacional y otros/acción declarativa de inconstitucionalidad y cobro de pesos. Fallos, 191:2009.

Omnia. Derecho y sociedad, núm. 3, 2020: 55-82 79 
CSJN. (24/11/2015). Santa Fe, Provincia de c/ Estado Nacional s/acción declarativa de inconstitucionalidad. Fallos, 538:2009.

CSJN. (2/5/2016). Provincia de San Luis c/Estado Nacional s/cobro de pesos. Expediente CSJ 315/2009.

Decreto $N^{\circ} 14 / 04$. Ratifícase el Pacto Federal para el Empleo, la Producción y el Crecimiento celebrado entre el Estado Nacional y los Estados Provinciales. Boletín Oficial de la República Argentina. Ciudad de Buenos Aires, Argentina. 6 de enero de 1964. Recuperado de http://servicios.infoleg.gob.ar/ infolegInternet/anexos/5000-9999/9520/ norma.htm

Ekmekdjian, M. A. (1997). Tratado de derecho constitucional. Buenos Aires: Depalma.

Espeche, S. (2016). Curso de Derecho Financiero. Buenos Aires: Erreius.

Frías, P. J. (1974). Nación y provincias en el federalismo argentino. Córdoba: Boletín de la Facultad de Derecho y Ciencias Sociales, Universidad Nacional de Córdoba.

Frías, P. J. (1998). El proceso federal argentino. Córdoba: El Copista.

Garat, P. M. (2009a). El sistema argentino de coparticipación impositiva y los desafíos al régimen fiscal federal. Recuperado de http:// www.fundacioncivilidad.org.ar/index.php/ federalismo-fiscal [15/10/2018].

Garat, P. M. (2009b). El sistema de coparticipación federal en la organización constitucional argentina. Revista Latinoamericana de Derecho, 5(9-10), pp. 55-113.

Hernández, A. M. (2008). Aspectos fiscales y económicos del federalismo argentino. Córdoba: Academia Nacional de Derecho y Ciencias Sociales de Córdoba.

Ley $\mathrm{N}^{\circ}$ 20.221. Impuestos nacionales. Boletín Oficial de la República Argentina. Ciudad de Buenos Aires, Argentina. 21 de marzo de 1973. Recuperado de http:// servicios.infoleg.gob.ar/infoleglnternet/anexos/35000-39999/38936/norma.htm\#: : text $=$ El $\% 20$ proyecto $\% 20$ de\%20ley\%2Dconvenio, 14.788\%2C\%20 $14.390 \% 20 y \% 2014.060)$.\&text $=L a \% 20$ distribuci \% C $3 \%$ B 3 n \% 20 por \% 20 poblaci\%C3\%B3n\%20se,y\%20el\%20n\%C3\%BAmero\%20de\%20habitantes.

Ley $\mathrm{N}^{\circ}$ 23.548. Coparticipación federal de recursos fiscales. Boletín Oficial de la República Argentina. Ciudad de Buenos Aires, Argentina. 22 de enero de 1988. Recuperado de http://servicios.infoleg.gob.ar/infoleglnternet/anexos/20000-24999/21108/ texact.htm

Ley $\mathrm{N}^{\circ}$ 23.966. Financiamiento del régimen nacional de previsión social. Afectación del I.V.A. Impuesto sobre combustibles líquidos y gas natural. Modificaciones a la ley del fondo nacional de la vivienda. Derogación de regímenes de jubilaciones especiales. Impuesto sobre los bienes personales no incorporado al proceso económico. Destino de los recursos de privatizaciones. Modificación de la ley de tasas judiciales. Boletín Oficial de la República Argentina. Ciudad de Buenos Aires, Argentina. 15 de agosto de 1991. Recuperado de http://servicios.infoleg.gob.ar/infoleglnternet/anexos/0-4999/365/texact.htm

Ley № 24.130. Ratificase el "Acuerdo entre el Gobierno nacional y los gobiernos provinciales", suscripto el 12 de agosto de 1992. Boletín Oficial de la República Argentina. Ciudad de Buenos Aires, Argentina. 17 de septiembre de 1992. Recuperado de http://servicios.infoleg. gob.ar/infoleglnternet/anexos/0-4999/17/ norma.htm\#: :text=Ley\%2024.130\%20 del\%202\%2F9\%2F92\&text=Ratificase $\% 20$ el $\% 20 \% 22$ A cuerd o $\% 20$ en tre $\% 20$ el,Promulgada\%20Septiembre\%2017\%20 de\%201992 
Ley $N^{\circ}$ 24.464. Sistema Federal de la Vivienda. Boletín Oficial de la República Argentina. Ciudad de Buenos Aires, Argentina. 8 de marzo de 1995. Recuperado de http://servicios.infoleg.gob.ar/infoleglnternet/anexos/15000-19999/16331/ texact.htm\#: :text=Sancionada\%3A\%20 M a r z o \% $208 \% 20$ d e \% 20 1995,Parcialmente\%3 A\%20Marzo\%20 27\%20de\%201995.\&text=ARTICULO\%20 $1 \%$ C 2\%BA\%20\%2DCr\%C3\%A9ase \%20 el\%20Sistema,acceso\%20a\%20la\%20vivienda\%20digna

Ley $\mathrm{N}^{\circ}$ 26.078. Presupuesto general de la administración nacional. Boletín Oficial de la República Argentina. Ciudad de Buenos Aires, Argentina. 9 de enero de 2006. Recuperado de http://servicios.infoleg.gob.ar/infoleglnternet/anexos/110000-114999/112978/norma.htm

Ley $\mathrm{N}^{\circ}$ 27.429. Aprobación. Boletín Oficial de la República Argentina. Ciudad de Buenos Aires, Argentina. 2 de enero de 2018. Recuperado de http://servicios. infoleg.gob.ar/infoleglnternet/anexos/305000-309999/305349/norma.htm

Ley N²7.542. Aprobación. Boletín Oficial de la República Argentina. Ciudad de Buenos Aires, Argentina. 12 de febrero de 2020. Recuperado de https://www.boletinoficial.gob. ar/detalleAviso/primera/225364/20200212

Ley No 24.049. Facúltase al P.E.N. a transferir a las provincias a la Municipalidad de la Ciudad de Buenos Aires, los servicios educativos administrados en forma directa por el Ministerio de Cultura y Educación y por el Consejo Nacional de Educación Técnica y las facultades y funciones sobre los establecimientos privados reconocidos. Excepciones. Boletín Oficial de la República Argentina. Ciudad de Buenos Aires, Argentina. 2 de enero de 1992. Recuperado de http:// servicios.infoleg.gob.ar/infoleglnternet/ anexos/0-4999/448/norma.htm

Ley No 25.235. Acuerdos. Boletín Oficial de la República Argentina. Ciudad de Buenos Aires, Argentina. 30 de diciembre de 1999. Recuperado de http://servicios.infoleg.gob.ar/infoleglnternet/anexos/60000-64999/61898/norma.htm

Ley No 25.400. Acuerdos. Boletín Oficial de la República Argentina. Ciudad de Buenos Aires, Argentina. 8 de enero de 2001. Recuperado de http://servicios.infoleg.gob.ar/infoleglnternet/anexos/65000-69999/65718/ norma.htm

Llambias, J. J. Banegas Raffo, P. Sassot, R. A. (1997) Manual de Derecho Civil, Obligaciones. Buenos Aires: Abeledo Perrot.

Messineo, F. (1954). Manual de Derecho Civil y Comercial. Buenos Aires: EJEA.

Montes, A. C. (1995). La vía subrogatorias. Madrid:Tecnos.

Nicoló, R. (1953). Azione surrogatoria-revocatoria. En Scialoja y Branca (Coord). Commentario del Codice Civile. Bolonia: ZanicheIli Editore.

Pérez Hualde, A. (1999). Coparticipación Federal de Impuestos en la Constitución Nacional. Buenos Aires: Depalma.

Pizarro, R. D. y Vallespinos, C. G. (1999). Instituciones de Derecho Privado - Obligaciones. Buenos Aires: Hammurabi.

Sánchez de Bustamante, M. (1945). Acción oblicua, indirecta o subrogatorias. Buenos Aires: Edición de Jurisprudencia Argentina.

Sirvent García, J. (1997). La acción subrogatoria. Madrid: Universidad Carlos II de Madrid.

Spisso, R. (2007). La descentralización del sistema de coparticipación tributarios federal, instrumentos de destrucción de la Republica federal. Suplemento de Derecho Tributario, No 11.849, Año XLV. Buenos Aires: El Dial. 
Tobías Larregui

Spisso, R. (2016). Derecho Constitucional Tributario. Buenos Aires: Abeledo Perrot.

Spisso, R. R. (2018). El ejercicio de la potestad tri- butaria de los municipios y su sujeción a los Acuerdos de Armonización Tributaria. Buenos Aires: El Derecho. 